\title{
Review
}

\section{Nedd4 and Nedd4-2: closely related ubiquitin-protein ligases with distinct physiological functions}

\author{
B Yang ${ }^{\star, 1}$ and S Kumar ${ }^{\star 2}$
}

The Nedd4 (neural precursor cell-expressed developmentally downregulated gene 4) family of ubiquitin ligases (E3s) is characterized by a distinct modular domain architecture, with each member consisting of a C2 domain, 2-4 WW domains, and a HECT-type ligase domain. Of the nine mammalian members of this family, Nedd4 and its close relative, Nedd4-2, represent the ancestral ligases with strong similarity to the yeast, Rsp5. In Saccharomyces cerevisiae Rsp5 has a key role in regulating the trafficking, sorting, and degradation of a large number of proteins in multiple cellular compartments. However, in mammals the Nedd4 family members, including Nedd4 and Nedd4-2, appear to have distinct functions, thereby suggesting that these E3s target specific proteins for ubiquitylation. In this article we focus on the biology and emerging functions of Nedd4 and Nedd4-2, and review recent in vivo studies on these E3s.

Cell Death and Differentiation (2010) 17, 68-77; doi:10.1038/cdd.2009.84; published online 26 June 2009

Ubiquitylation controls biological signaling in many different ways. ${ }^{1,2}$ For example, the ubiquitylation of a misfolded or damaged protein leads to its degradation by the $26 \mathrm{~S}$ proteasome before it can get to its subcellular site where it normally functions. A ligand-activated receptor may undergo ubiquitylation, where the tagging with ubiquitin acts as a signal for the endocytosis of the receptor; thus, removal from the membrane resulting in the termination of the signal generated by the activated receptor. Ubiquitylation of a cell-cycle inhibitor could lead to its rapid degradation, allowing cells to progress through the cycle. Thus, protein ubiquitylation can control signaling by regulating the cellular levels of a protein, by controlling its subcellular localization, by preventing accumulation of defective or damaged proteins, and in some instances, by preventing protein degradation. Clearly, a process that is so critical for cellular homeostasis, is itself tightly regulated by multiple enzymatic steps and many accessory proteins that provide specificity to the system.

The ubiquitylation of a protein needs conjugation between the carboxyl group of the C-terminal Gly residue of ubiquitin, and the $\varepsilon$-amino group of an internal Lys $(K)$ in the substrate. ${ }^{1,2}$ The transfer of the activated ubiquitin to substrates occurs through a series of enzymes. These enzymes include a ubiquitin activating enzyme (E1), multiple ubiquitin conjugating enzymes (E2), and several hundreds of ubiquitin-protein ligase (E3). A protein can be monoubiquitylated, multi-monoubiquitylated, or polyubiquitylated, and the type of ubiquitylation determines the fate of the protein. ${ }^{1,2}$ Ubiquitin itself contains seven lysine residues, all of which can participate in the formation of ubiquitin chains. However, in mammals, K48 and K63 linked chains are most common. ${ }^{1,2}$ Substrates containing K48 linked ubiquitin chains are usually degraded by the $26 \mathrm{~S}$ proteasome, whereas those containing K63 linked chains may undergo a number of different outcomes, including trafficking and/or lysosomal degradation. Recent work demonstrates that polyubiquitin chains through six of the seven Lys residues in ubiquitin (with the exception of K63), can target proteins for degradation. ${ }^{3}$ This study also showed that substrates linked through $\mathrm{K} 11$ chains are targets of endoplasmic reticulum-associated degradation (ERAD) pathway. ${ }^{3}$

\section{The HECT Ubiquitin-Protein Ligases}

The specificity of ubiquitylation system is critical and is largely regulated by the E3s, which are responsible for mediating the transfer of ubiquitin from E2 to the substrate. Given that many cellular proteins are ubiquitylated, there are over 600 putative E3s in mammals. There are two main classes of E3s; the RING (Really Interesting New Gene) E3s, and the HECT (

${ }^{1}$ Carver College of Medicine, University of lowa, lowa City, IA 52242, USA and ${ }^{2}$ Centre for Cancer Biology, SA Pathology and Hanson Institute, Adelaide, SA 5000, Australia

${ }^{*}$ Corresponding authors: B Yang, Obstetrics and Gynecology, University of lowa, 200 Hawkins Dr, 46 MRF, lowa City, lowa 52242, USA.

E-mail: baoli-yang@uiowa.edu; or S Kumar, CCB, SA Pathology, PO Box 14, Rundle Mall, Adelaide SA5000, Australia. E-mail: Sharad.Kumar@health.sa.gov.au Keywords: ubiquitylation; endocytosis; trafficking; receptor; signaling

Abbreviations: Nedd4, neural precursor cell-expressed developmentally downregulated gene 4; HECT, homologous to E6-AP C-terminus; RING, really interesting new gene; E6AP, human papilloma virus E6 associated protein; MAPK, mitogen-activated protein kinase; PI3K, phosphoinositide-3 kinase; ENaC, epithelial sodium channel; Grb10, growth factor receptor-bound protein 10; MEF, mouse embryonic fibroblast; PTEN, phosphatase and tensin homolog; ESCRT, endosomal sorting complex required for transport; LMP2A, latent membrane protein 2A; Sgk1, serum glucocorticoid-inducible kinase 1; Ndfip, Nedd4 family interacting protein; DMT1, divalent metal ion transporter 1.

Received 20.3.09; revised 29.4.09; accepted 27.5.09; Edited by G Melino; published online 26.6.09 
accept ubiquitin from an E2 and is then transferred to the substrate. On the other hand RING E3s mediate the E2-substrate interaction to facilitate the transfer of ubiquitin directly from an E2 to the substrate. Most human E3s belong to the RING family, whereas HECT family consists of 28 proteins. HECT is an $\sim 350$ amino-acid domain that was first described in E6AP (human papilloma virus E6 Associated Protein). ${ }^{5}$ Although a number of proteins containing HECT domain, including the Sacchromyces cerevisiae protein, Rsp5, and the mouse Nedd4 (neural precursor cell-expressed developmentally downregulated gene 4), were deposited in the public databases around the same time when E6AP was cloned, ${ }^{6,7}$ the function of the HECT as a ubiquitin ligase only became apparent from studies on E6AP. ${ }^{5,8}$ E6AP binds human papillomavirus (HPV) E6 oncoprotein and acts as a ubiquitin ligase for p53 in HPV infected cells. ${ }^{9}$ HECT domains are usually found at the C-termini of proteins. It is a bilobal domain, in which the two lobes are bridged by a flexible hinge loop. ${ }^{10}$ The $\mathrm{E} 2$ binds to the $\mathrm{N}$-terminal lobe, opposite to the C-terminal lobe, which also carries the catalytic Cys residue. Substrate binding is defined by regions outside the HECT, in most cases, towards the $\mathrm{N}$-terminus of the protein. Based on domain architecture, majority of the HECT E3s belong to two families: the Nedd4 family and the HERC family. ${ }^{4}$

\section{Nedd4 and Nedd4-2}

The Nedd4 family contains nine members in human including NEDD4, NEDD4-2 (NEDD4L), ITCH, SMURF1, SMURF2, WWP1, WWP2, NEDL1, and NEDL2. ${ }^{11-13}$ Nedd4 and Nedd4-
2 , the subjects of this review, are most closely related to each other. The phylogenetic analysis of these proteins from various species (Figure 1a) indicates that Nedd4 is the likely ancestral member of the family, whereas Nedd4-2 originated later in evolution, perhaps by gene duplication. Thus, Nedd4 is closely related to Rsp5 in $S$. cerevisiae, which has only a single member of the Nedd4 family. There are four members of the Nedd4 family in Drosophila melanogaster, including dNedd, but there are no Nedd4-2 orthologues (Figure 1). All vertebrates appear to have both Nedd4 and Nedd4-2 genes. Nedd4 and Nedd4-2 have identical specificity for ubiquitin conjugating enzymes (E2). ${ }^{14}$ The prototypic member of the family, Nedd4, was discovered as a developmentally regulated gene in the central nervous system of mouse.6,15 It contains an $\mathrm{N}$-terminal calcium/lipid and/or protein binding C2 domain, 3 (in mouse and rat) or 4 (in human) WW domains (protein-protein interaction domains), and a C-terminal HECT domain (Figure 1b). This modular domain structure is characteristic of all the Nedd4 family members, the only variable being the number of WW domains, with the mammalian Nedd4 family members containing 2-4 of these domains. ${ }^{12,13,16} \mathrm{WW}$ domains are the main determinants of substrate binding by the Nedd4 E3s, although other regions, such as the C2 domain of Nedd4, can also bind substrates. ${ }^{17}$ Given the presence of multiple WW domains in Nedd4 and Nedd4-2, these E3 can potentially interact with several substrates (or regulatory proteins). The Nedd4 and Nedd4-2 WW domains can bind PPXY (PY) or LPSY motifs, and in vitro studies suggest that WW3 and WW4 of both proteins bind PY motifs in the key substrates, with WW3 generally exhibiting a

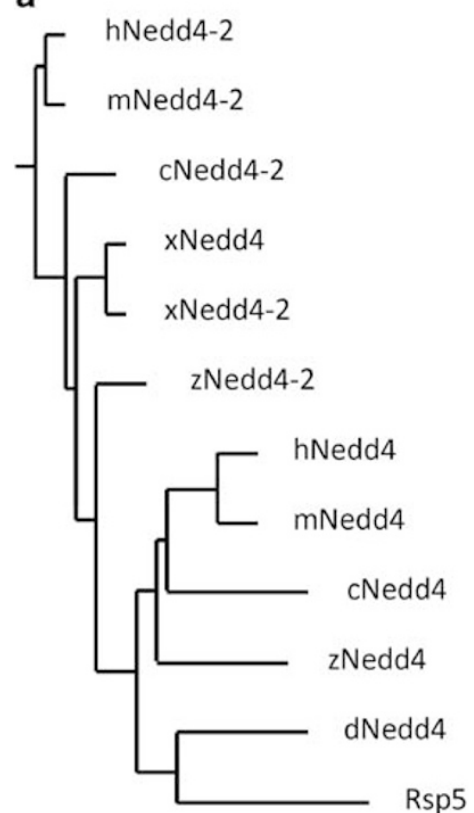

b
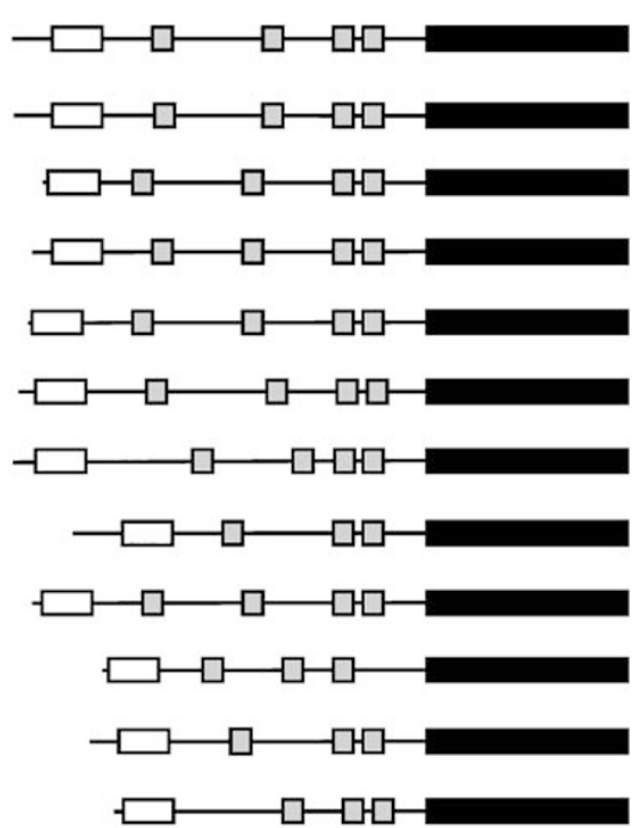

Figure 1 Phylogenetic relationship between the Nedd4 and Nedd4-2 among selected species. (a) Phylogenetic tree of Nedd4 and Nedd4-2 ubiquitin ligases. (b) The modular protein domain structures of Nedd4 and Nedd4-2 from selected species. The protein sequences and domain structure were compared between Nedd4 and Nedd4-2 among different species, including the yeast homolog, Rsp5. The open boxes are the C2 domains, the grey boxes are the WW domains, and the closed boxes are the HECT domains. The length of each box is proportional to the domain size. The domain structures were defined by PROSITE profiles (www.expasy.org/prosite). The protein information was obtained from Ensembl (www.ensembl.org). Protein sequence alignment and phylogenetic tree construction were carried out at Biology WorkBench (http://workbench.sdsc.edu). c: chicken (Gallus gallus); d: fruitfly (Drosophila melanogaster); h: human (Homo sapiens); m: mouse (Mus musculus); x: frog (Xenopus tropicalis); and z: zebrafish (Danio rerio) 
higher affinity. ${ }^{11,16,18,19}$ Most Nedd4 family members, especially Nedd4-2, also have multiple splice variants, which might play different roles in regulating their substrates. ${ }^{20,21}$

\section{Nedd4 Targets and Function}

The first described target of Nedd4 was the epithelial sodium channel $(\mathrm{ENaC}) .{ }^{22}$ However, after the discovery of Nedd4-2, it was suggested that Nedd4 and Nedd4-2 probably have redundant functions in $\mathrm{ENaC}$ regulation. ${ }^{23-25}$ Subsequently, a number of potential substrates for Nedd4 have been described and a partial list of these is shown in Table 1. Many of these targets have been identified by the use of heterologous or in vitro systems, thus their functional significance in vivo remains to be fully explored. Here we discuss the main pathways/targets regulated by Nedd4.

Growth factor receptor regulation by Nedd4. Nedd4 has been implicated in the downregulation of growth factor receptors through biochemical analyses of cells transfected with Nedd4. ${ }^{26}$ Many types of receptors have been studied, including epidermal growth factor receptor (EGFR), ${ }^{27}$ vascular endothelial growth factor receptor-2 (VEGF-R2), ${ }^{28}$

Table 1 Potential substrates and/or binding partners of Nedd4 and Nedd4-2

\begin{tabular}{|c|c|c|}
\hline \multicolumn{3}{|l|}{ Nedd4 } \\
\hline$\beta 2-A R$ & $\beta 2$-adrenergic receptor & 92 \\
\hline $\mathrm{Cbl}$ & Casitas B-lineage lymphoma & $38,40,93$ \\
\hline connexin43 & Gap junction protein & 94 \\
\hline EGFR & Endothelial growth factor receptor & 27,95 \\
\hline $\mathrm{ENaC}$ & Epithelial sodium channel & 22,96 \\
\hline ү2-Adaptin & Ubiquitin-interacting adaptor & 97 \\
\hline MTMR4 & Inositol phosphatase & 98 \\
\hline $\mathrm{Na}_{v}$ & Voltage-gated sodium channels & 52,53 \\
\hline Notch1 & Notch homolog 1 & 99,100 \\
\hline pol II & RNA polymerase II & 101 \\
\hline Smad4 & $\begin{array}{l}\text { Mothers against decapentaplegic } \\
\text { homolog } 4\end{array}$ & 102 \\
\hline Spy1A & Cyclin-dependent kinase activator & 103 \\
\hline VEGF-R2 & $\begin{array}{l}\text { Vascular endothelial growth factor } \\
\text { receptor-2 }\end{array}$ & 28 \\
\hline \multicolumn{3}{|l|}{ Nedd4-2 } \\
\hline $14-3-3$ & Adaptor/regulatory protein & 73,74 \\
\hline ACK1 & Activated Cdc42-associated kinase 1 & 104 \\
\hline ATA2 & Amino acid transporter & 105 \\
\hline CIC-5 & Chloride ion channels & 106 \\
\hline CLC-Ka/barttin & Chloride ion channels & 107 \\
\hline DT & Dopamine transporter & 108 \\
\hline EAAT1/2 & Glutamate transporter & 109,110 \\
\hline $\mathrm{ENaC}$ & Epithelial sodium channel & 23,24 \\
\hline $\begin{array}{l}\mathrm{KCNQ} 1, \\
\mathrm{KCNQ} 2 / 3 \text {, and }\end{array}$ & Voltage-gated $\mathrm{K}^{(+)}$channels & 111,112 \\
\hline KCNQ3/5 & & \\
\hline $\mathrm{K}_{\mathrm{V}} 1.3$ & Voltage gated $\mathrm{K}^{+}$channel & 113 \\
\hline $\mathrm{K}_{\mathrm{v}} 4.3$ & Cardiac shal-related potassium channel & 114 \\
\hline $\mathrm{NaPi} I \mathrm{lb}$ & Intestinal phosphate cotransporter & 115 \\
\hline $\mathrm{Na}_{\mathrm{v}}$ (several) & Voltage-gated sodium channels & $52-54$ \\
\hline Nedd4-2 & Ubiquitin ligase & 83 \\
\hline Sgk1 & Serum glucocorticoid-inducible kinase & 56 \\
\hline SGLT1 & Glucose transporter & 84 \\
\hline SP-C & Surfactant protein C & 57,58 \\
\hline Smad4 & $\begin{array}{l}\text { Mothers against decapentaplegic } \\
\text { homolog } 4\end{array}$ & 102 \\
\hline TGF $\beta$ & Transforming growth factor- $\beta$ & 116 \\
\hline Trk & Trk neurotrophin receptors & 117 \\
\hline Tweety & Chloride ion channels & 118 \\
\hline
\end{tabular}

insulin receptor, and IGF-1R. ${ }^{29}$ However, the gene knockout (KO) studies indicate that one of the main in vivo functions of Nedd4 is the regulation of IGF-1R, and perhaps insulin receptor (IR). ${ }^{30,31}$ The predominant phenotype of Nedd4 KO mice is growth retardation (with a body weight less than $40 \%$ of that of wild type littermates), and associated perinatal lethality. ${ }^{30}$ Consistent with the overall growth retardation, mouse embryonic fibroblasts (MEFs) isolated from Nedd4 KO embryos show slower growth, and respond poorly to serum after serum starvation than cells isolated from wild type embryos. ${ }^{30}$ Both IGF-1R and IR signaling are affected by Nedd4 deficiency. Three lines of evidence conveyed this point. (i) Both MAPK and PI3K signaling pathways were diminished in the Nedd4 ${ }^{-1-}$ cells when stimulated with IGF-1 or insulin, with PI3K pathway affected more severely; (ii) cell surface expression of IGF-1R and IR were reduced in the Nedd4 KO cells; and (iii) Nedd4 action was mediated by Grb10. ${ }^{30}$ Grb10 has been shown previously to interact with Nedd4. ${ }^{26}$ However, earlier studies, in contrast to the KO mouse data, suggested that Grb10 acts as an adaptor for Nedd4 to ubiquitylate IGF-1R. ${ }^{32}$ The mouse KO data indicate that Grb10 levels are elevated in Nedd4 ${ }^{-1-}$ MEFs, ${ }^{30}$ although Grb10 is not a direct target of the Nedd4-mediated ubiquitylation. ${ }^{30}$ It is important to note that the lethality in Nedd4-/- mice was partially rescued by maternal inheritance of a disrupted Grb10 allele. ${ }^{30}$

The interactions between Nedd4 and IGF-1R/IR appear to be receptor specific. The signaling cascade propagated from a distinct transmembrane tyrosine kinase receptor, EGFR, was not affected in the Nedd4 ${ }^{-1-}$ MEFs. ${ }^{30}$ Therefore, it is unlikely that Nedd4 serves as a ubiquitous component of the endocytic machinery for all growth factor receptors.

It is clear from these physiological and cellular studies that Nedd4 is a positive regulator of growth and proliferation, especially during embryonic development, through interactions with IGF-1R/IR; however, the details of these interactions are still not clear. As other ubiquitin ligases, such as Mdm2 and $\mathrm{c}-\mathrm{Cbl},{ }^{33,34}$ in addition to Nedd4, ${ }^{32}$ have been implicated in mediating ubiquitylation of IGF-1R, two models of potential interaction have been proposed and are being tested: sequential ubiquitylation and competing ubiquitylation (Figure 2). In the first model, Nedd4 does not directly ubiquitylate IGF-1R, but controls the activity of another E3 (Mdm2, c-Cbl, or another ubiquitin ligase), which in turn is responsible for IGF-1R ubiquitylation and degradation. In the competing ubiquitylation model, both Nedd4 and the other E3 directly ubiquitylate IGF-1R; however, Nedd4-mediated IGF-1R ubiquitylation does not lead to its degradation through the proteasome. Both models can explain the current result that Nedd4 deficiency results in increased endocytosis of IGF-1R and reduced IGF-1 signaling.

Regulation of T-cell function by Nedd4. The potential involvement of Nedd4 in T-cell activation was first suggested by Heissmeyer et al. ${ }^{35}$ In this study it was concluded that Itch, a closely related family member of Nedd4, and possibly Nedd4, contribute to $T$ cell anergy - a state of T-cell unresponsiveness induced when $T$ cells are stimulated through the T-cell receptor in the absence of co-stimulation. The authors showed that unresponsiveness occurs, in part, 


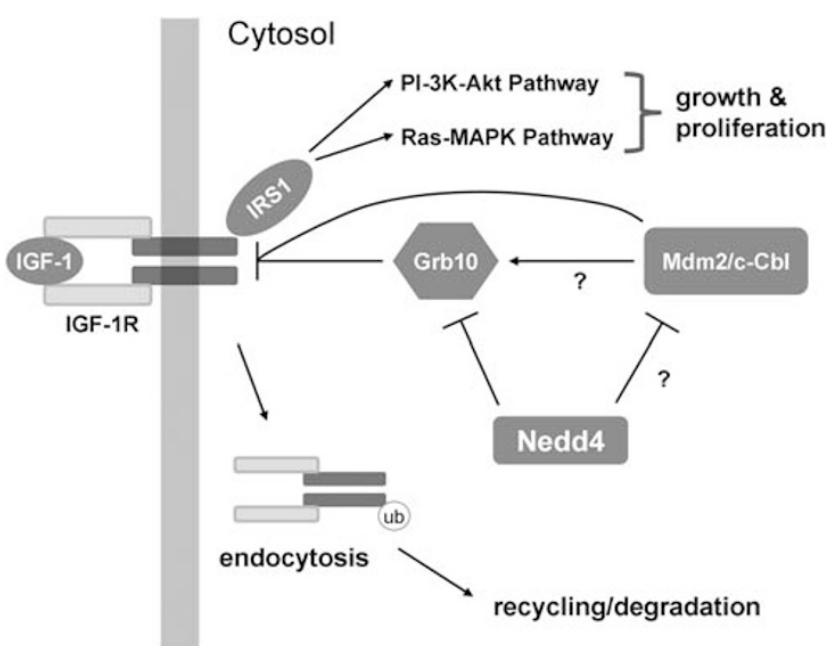

Figure 2 A possible model of Nedd4 function in regulating IGF-1 signaling. Ligand (IGF-1) interaction with IGF-1R results in autophosphorylation of the receptor, which then phosphorylates insulin receptor substrates, such as IRS1. IRS molecules act as docking sites for other proteins, which lead to the activation of both PI3K (phosphoinositide-3 kinase) and MAPK (mitogen-activated protein kinase) signaling pathways, and growth and proliferation of the cells. IGF-1R activity is regulated by ubiquitin-mediated endocytosis, and the endocytosed receptors can be degraded or recycled back to the plasma membrane. Nedd4 might have multiple roles in the regulation of IGF-1R. Nedd4 has been shown to be involved in the downregulation of Grb10, an adaptor protein which binds directly to IGF-1R. Grb10 has been proposed to mediate the interaction between IGF-1R and Nedd4. Other ubiquitin ligases, such as Mdm2 and c-Cbl, have been shown to target IGF-1R for degradation. It is not clear, whether these interactions are mediated by Grb10

because $\operatorname{PKC} \theta$ and PLC $\gamma 1$ are degraded by a ubiquitindependent process. The role that Nedd4 played in this process was not entirely clear, and because of the high degree of similarity between Itch and Nedd4, it was suggested that they have overlapping functions. ${ }^{36}$ However, Itch and Nedd4 deficient mice exhibit different phenotypes, suggesting that these two E3-ubiquitin ligases regulate distinct pathways in vivo. ${ }^{37,38}$

As mentioned earlier, mice lacking Nedd4 are perinatal lethal due to a severe growth retardation. ${ }^{30}$ To study the role of Nedd4 in T cells, fetal liver chimeras (Nedd4 ${ }^{-/-\mathrm{FLCh}}$ ) in which Nedd4 was only deficient in cells of hematopoietic origin were generated. ${ }^{38}$ Mice lacking Nedd $4\left(\mathrm{Nedd} 4^{-\prime-}\right)$ displayed normal T-cell development in the thymus, but their T cells in the periphery were hypo-responsive. Nedd4 ${ }^{-1-} \mathrm{T}$ cells proliferate poorly in response to antigen and are less likely to produce IL-2. Furthermore, their B cells undergo class switching with lower frequency. ${ }^{38}$ In contrast, mice lacking Itch have hyper-responsive $T$ cells ${ }^{39}$ that are skewed towards T-helper type 2 (Th2) cytokine production. This is due to the well-described role for Itch in ubiquitylation of JunB, a transcription factor that promotes Th2 cytokine production. From these results, it was reasoned that Nedd4 likely promotes T-cell activation and enhancement of the adaptive immune response, whereas Itch prevents Th2 differentiation. The dissimilarities seen between the immunologic phenotypes of $\mathrm{Nedd}^{-1-}$ and Itch ${ }^{-1-}$ mice suggest that these E3 ligases ubiquitylate unique targets and thus, function quite differently in the regulation of $\mathrm{T}$ cell responses. Thus, while the
Th2-mediated disease in Itch mutant mice can be explained by the loss of Itch-mediated degradation of JunB, it was found that the diminished activation of $\mathrm{Nedd4}^{-1-} \mathrm{T}$ cells can be explained by the lack of ubiquitylation and degradation of Cbl-b. Nedd4 ${ }^{-1-}$ T cells contained increased levels of Cbl-b protein because Nedd4 is needed for the polyubiquitylation of Cbl-b. ${ }^{38,40}$ Although these data support that these two E3 ligases act on a unique subset of targets, further studies are needed to address whether this is true for all Nedd4 and Itch targets, or whether these ligases share the responsibility of ubiquitylating some targets.

Nedd4 regulates neuromuscular junctions. In addition to the phenotypes of Nedd $4 \mathrm{KO}$ mice described above, a recent study of the $\mathrm{Nedd4}^{-/-}$embryos indicate that this E3 is also needed for the proper formation and functioning of the neuromuscular junctions. ${ }^{41} \mathrm{Nedd} 4$ is highly expressed in skeletal muscle. In Nedd4 ${ }^{-1-}$ embryos the size of skeletal muscle fibers and the number of motor neurons were reduced, even though, very interestingly, Nedd4 is not expressed in motor neurons. This suggests that the function of Nedd4 in this system is non-cell autonomous. A detailed analysis indicated that Nedd4 regulates the interaction between the motor neurons and the muscle, especially nerve fasciculation. In the $\mathrm{KO}$ embryos, the presynaptic nerve terminal branches at the neuromuscular junctions are reduced in diameter but increased in number. ${ }^{41}$ Although these studies clearly define an important role of Nedd4 in regulating neuromuscular junctions, the mechanism by which this occurs remains unknown. Furthermore, it is unclear whether the motor neuron and skeletal muscle fiber phenotypes are directly due to the defective regulation of the formation and functioning of the neuromuscular junctions. The discovery of the substrate(s) of Nedd4 responsible for these phenotypes in the Nedd4 $\mathrm{KO}$ mice will delineate the precise mechanisms by which Nedd4 controls the size of skeletal muscle fibers and the number of motor neurons.

Regulation of VEGF-R2 by Nedd4. Another potential target of Nedd4 is VEGF-R2. ${ }^{28}$ In this system Grb10 protein is a positive regulator of VEGF signaling; VEGF enhances Grb10 expression, and Grb10 overexpression induces increased Tyr phosphorylation of VEGF-R2 and increased accumulation of this protein. ${ }^{42} \mathrm{~A}$ study by Murdaca et al. ${ }^{28}$ found that Nedd4 mediates VEGF-R2 degradation and Grb10 inhibits this by binding to Nedd4. It is interesting to note that although VEGF-R2 is ubiquitylated, Nedd4 does not directly mediate this ubiquitylation. Given that Nedd4 $\mathrm{KO}$ mice accumulate $\mathrm{Grb} 10,{ }^{30}$ it will be interesting to study whether the loss of Nedd4 leads to increased VEGF-R2 protein and a deregulation of vasculogenesis and angiogenesis.

Does Nedd4 play a role in the regulation of PTEN? It was previously reported that PTEN is ubiquitylated and degraded in the cells, and biochemical purification using HeLa cell lysate showed that Nedd4 was the putative E3 responsible for PTEN ubiquitylation ${ }^{43}$ and nuclear localization. ${ }^{44}$ As $P T E N$ is one of the major tumor 
suppressor genes, these reports suggested an important role for NEDD4 as an oncogene. ${ }^{43}$ In supporting the role of Nedd4 in regulating PTEN, it was shown that Nedd4 is upreguated in certain type of tumors when compared with nearby normal tissue. ${ }^{44}$ As the interaction between Nedd4 and PTEN was based largely on studies using heterologous expression system with either Nedd4 or Nedd4 and PTEN both overexpressed in cultured cells, it prompted the testing of this interaction in Nedd4 deficient cells from gene $\mathrm{KO}$ mice. Independent studies from a number of Nedd4 KO lines have failed to detect changes in the amount of PTEN in MEFs. ${ }^{30,31,38}$ In addition the stability and localization of PTEN were not affected by the absence of Nedd4. ${ }^{31,38}$ Furthermore, the results obtained using siRNA knockdown of Nedd4 presented in the earlier reports ${ }^{43,44}$ could not be reproduced. $^{31,38}$ Overall, these results argue against a general role of Nedd4 in PTEN stability and localization. However, to fully resolve this controversy, additional work may be needed, for example, to establish if Nedd4 has any cell-type specific function (such as in human tumor cells) in PTEN regulation.

Regulation of viral budding by Nedd4. Once mammalian cells are infected with viruses, virus replicates within the cells and exhausts the host cells to make viral progenies. The progenies leave the host cells via several routes, and one of them is called viral budding. ${ }^{45} \mathrm{Nedd} 4$ and Nedd4-like proteins (including Nedd4-2) have been implicated in this process for many viruses including the Epstein-Barr virus, ${ }^{46}$ retrovirus, ${ }^{47}$ and Ebola virus. ${ }^{48}$ These viruses contain motifs that interact with Nedd4 or Nedd4-2 WW domains, leading to the ubiquitylation of viral matrix protein and recognition by the cellular ESCRT machinery. One of the best described viral proteins involved in Nedd4 interaction is the latent membrane protein 2A (LMP2A) of the Epstein-Barr virus. ${ }^{46}$ Through the $P Y$ motifs at its N-terminus LMP2A recruits the Nedd4 family of E3s, leading to the ubiquitylation of LMP2A and LMP2Aassociated proteins, such as Lyn. ${ }^{46}$ Ubiquitylation of viral proteins serves as a signal for trafficking through the host cell's vesicular transport machinery, however the precise mechanisms of viral egress are not fully understood.

\section{Nedd4-2 Targets and Function}

Regulation of ENaC. Similar to Nedd4, there is a growing list of proteins that can be targeted by Nedd4-2 (Table 1). Of those the best-characterized target is ENaC (Figure 3). Extensive in vitro evidence existed from heterologous overexpression systems or biochemical analyses that Nedd4-2 targets ENaC for endocytosis and degradation, and it was predicted that the disruption of the interaction between Nedd4-2 and ENaC by mutations at the C-termini of either $\beta$ - or $\gamma$-ENaC subunit was the cause of Liddle's syndrome, an autosomal dominant disorder with severe sodium retention and hypertension. ${ }^{22,23}$ However, the in vivo evidence was lacking until recently to support the functional interaction between Nedd4-2 and ENaC. The mice expressing a mutant $\beta$-ENaC-PY motif 49 have saltsensitive hypertension (Liddle's mouse), and recently published data show that an absence of Nedd4-2 leads to

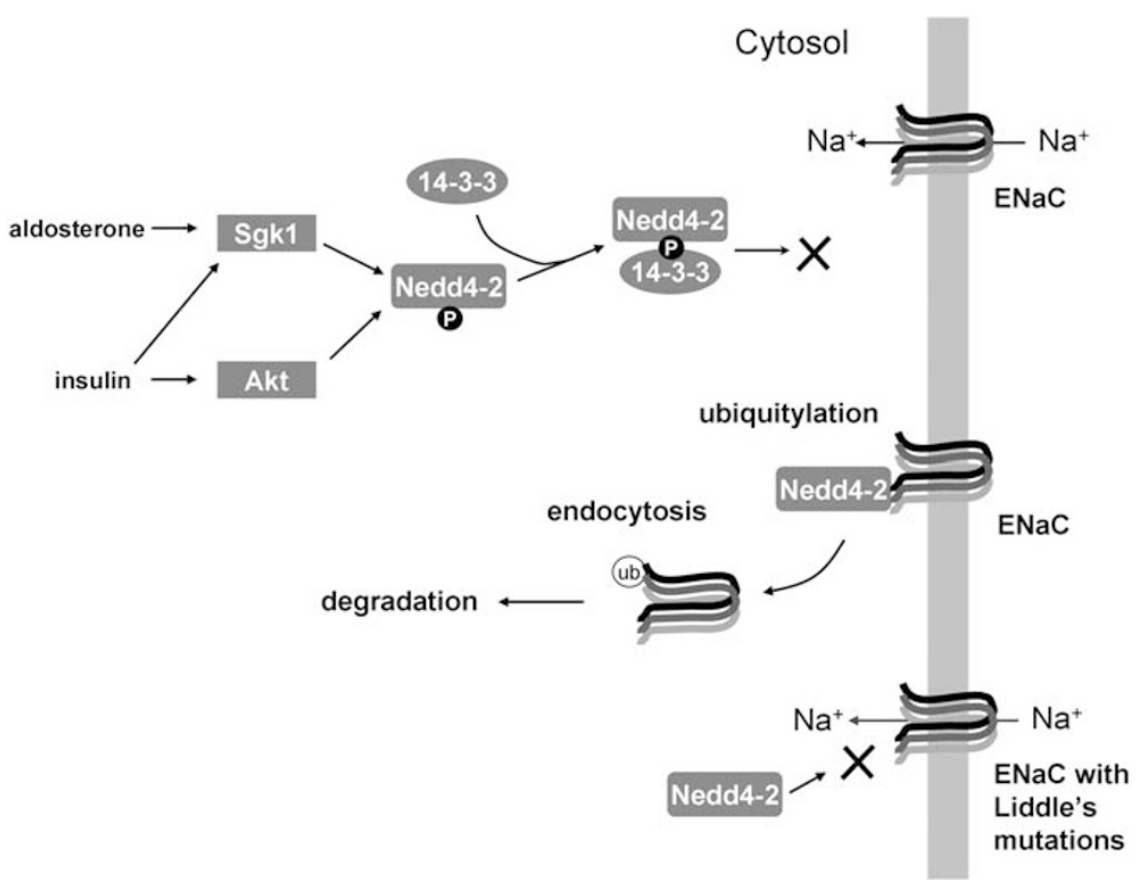

Figure 3 Nedd4-2 function in regulating epithelial sodium channel (ENaC). Nedd4-2 has been shown to bind directly with and ubiquitylate ENaC, and disruption of this interaction leads to increased ENaC surface expression and activity, as seen in Liddle's syndrome. Nedd4-2 is (in part) the converging point for both aldosterone and insulin signals, mediated through Sgk1 (serum glucocorticoid-inducible kinase) and Akt (also called protein kinase B, PKB), respectively. Phosphorylated Nedd4-2 can bind to 14-3-3, a phospho-protein binding protein, which inhibits the interaction between Nedd4-2 and ENaC 
hypertension in animals on a normal diet, and to marked saltsensitivity of this hypertension. ${ }^{50}$ However, the analysis of the Nedd4-2 KO mice identified some features that, when contrasted with those of the Liddle's mouse, raise important questions about the precise mechanistic role of Nedd4-2 in hypertension. Specifically, the Nedd4-2 KO mice are more hypertensive than Liddle's mice, and they do not display the degree of hypokalemia ${ }^{51}$ seen in Liddle's mice. These differences suggest that Nedd4-2 not only regulates ENaC, but may also affect blood pressure control by other means.

The observed hypertension in Nedd4-2 KO mice was probably mediated by increased ENaC activity because (i) all three $\mathrm{ENaC}$ subunits (but not other $\mathrm{Na}^{+}$transporters in the kidney) were expressed in the kidney at higher levels in Nedd4-2 KO mice than in their wild-type counterparts; (ii) the downregulation of $\mathrm{ENaC}$ function in the colon was impaired in Nedd4-2 KO mice; and (iii) salt-sensitive hypertension was substantially reduced in the presence of amiloride, a specific inhibitor of ENaC. ${ }^{50} \mathrm{Nedd} 4-2 \mathrm{KO}$ mice on a chronic high-salt diet also showed cardiac hypertrophy and markedly depressed cardiac function, symptoms that are also associated with chronic hypertension. Overall, the results from this $\mathrm{KO}$ study show that, in vivo, Nedd4-2 is critical regulator of ENaC activity and blood pressure, and that the absence of the encoding gene is sufficient to produce salt-sensitive hypertension. ${ }^{50}$

An additional Nedd4-2 $\mathrm{KO}$ line in a different genetic background has also been generated $(\mathrm{N}$. Boase and S. Kumar, unpublished data). These KO animals show perinatal lethality with some animals surviving up to 3 weeks after birth. The primary cause of perinatal lethality appears to be respiratory distress because of collapsed lungs, whereas the survivors develop severe inflammation of the lungs. These phenotypes are also consistent with increased activity of the $\mathrm{ENaC}$ in the Nedd4-2 KO mice (N. Boase and S. Kumar, unpublished data), again suggesting that Nedd4-2 is an essential regulator ENaC.

Regulation of voltage-gated sodium channels $\left(\mathrm{Na}_{\mathrm{v}} \mathrm{s}\right)$. In addition to the ENaC, several voltage gated sodium channels $\left(\mathrm{Na}_{\mathrm{v}} \mathrm{s}\right)$ are potential targets for regulation by Nedd4-2. ${ }^{52-54}$ In cells that can be electrically excited, $\mathrm{Na}_{\mathrm{v}} \mathrm{s}$ has a key role in generating and propagating action potentials. These channels are thus crucial for the functioning of many cells. For example, in the nervous system where many $\mathrm{Na}_{\mathrm{v}} \mathrm{s}$ are expressed, these channels are needed for the development and plasticity, and the maintenance of excitability following nerve and tissue injury. The pore forming $\alpha$-subunits of seven of the nine $\mathrm{Na}_{\mathrm{v}} \mathrm{s}$ contain typical PY motifs. Indeed, in vitro the PY motif containing $\mathrm{Na}_{\mathrm{v}} \mathrm{s}$ bind Nedd4-2 (and also Nedd4) WW domains. ${ }^{52}$ Several of these PY motif containing $\mathrm{Na}_{\mathrm{v}} \mathrm{s}$ were shown to be ubiquitylated by Nedd4-2. ${ }^{52-54}$ Furthermore, in Xenopus oocytes, Nedd4-2 strongly inhibited the activities of a number of $\mathrm{Na}_{\mathrm{v}} \mathrm{s}$, including the cardiac $\mathrm{Na}_{\mathrm{v}}\left(\mathrm{Na}_{\mathrm{v}} 1.5\right){ }^{53,54}$ and the neuronal $\mathrm{Na}_{\mathrm{v}} \mathrm{S}\left(\mathrm{Na}_{\mathrm{v}} 1.2\right.$, $\mathrm{Na}_{v} 1.7$, and $\left.\mathrm{Na}_{v} 1.8\right){ }^{52}$ In the Xenopus oocyte system, Nedd4 also suppressed the activities of $\mathrm{Na}_{\mathrm{v}} 1.2$ and $\mathrm{Na}_{\mathrm{v}} 1.7$, but it was a poor inhibitor of $\mathrm{Na}_{v} 1.7 .^{52}$ The in vivo validation of these findings awaits further studies using cells derived from the $\mathrm{KO}$ mice.
Regulation of Sgk1. A recent study showed that Sgk1 protein levels are regulated by the ubiquitin proteasome pathway, adding another dimension to the mechanism of regulation of this unusual serine-threonine kinase. ${ }^{55,56}$ That polyubiquitin-modified Sgk1 is predominantly localized to the membrane-associated fraction of the cell, suggests that Sgk1 is ubiquitylated at or near the membrane rather than in the cytosol. Overexpression of Nedd4-2 decreased Sgk1 expression by inducing polyubiquitylation and degradation of Sgk1 in the 26S proteasome. Conversely, Nedd4-2 siRNA stabilized Sgk1. ${ }^{56}$ This raises the interesting possibility that Sgk1 may both phosphorylate (see below) and act as a substrate of Nedd4-2, thereby achieving a tight negative feedback regulation of Nedd4-2 and Sgk1. Regulation of serine-threonine kinases by ubiquitin modification underscores the potential importance of phosphorylationindependent mechanisms in the regulation of signaling molecules.

Nedd4-2 mediated surfactant protein C (SP-C) trafficking. Two recent reports have suggested that Nedd4-2, and to a lesser extent Nedd4, contributes to the trafficking of surfactant protein C (SP-C). ${ }^{57,58}$ Pulmonary surfactant, a phospholipid-rich film synthesized and secreted by alveolar type-II epithelial cells, is the mixture of lipids and proteins needed to reduce surface tension. Deficiency of pulmonary surfactant is the principal cause of respiratory distress syndrome in premature infants. ${ }^{59}$ SP-C is a hydrophobic protein that enhances the surface-tensionlowering properties of surfactant lipids. Mutations in the $S P-C$ gene have been linked to the development of interstitial lung disease. ${ }^{60} \mathrm{~A}$ PY motif (PPDY) is present at the $\mathrm{N}$-terminus of SP-C pro-protein, and is conserved across all species. Mutations within the PY motif abrogated binding of SP-C to Nedd4-2 and completely blocked secretion of SP-C. ${ }^{57,58}$ However, knockdown of Nedd4-2 using siRNA or in Nedd4-2 KO cells, processing of proSP-C to mature peptide was not affected; ${ }^{58}$ whereas the other study showed that the processing was blocked by siRNA. ${ }^{57}$ As different cell types were used in these two studies, these observations need further validation.

\section{Regulation of Nedd4 and Nedd4-2}

There are a number of ways Nedd4 and Nedd4-2 E3s are regulated. As described below, these ligases can be regulated by binding of proteins that either assist (e.g. Ndfips) or preclude (e.g. 14-3-3) recruitment of the substrates. In addition, both Nedd4 and Nedd4-2 are likely to be regulated by phosphorylation and intramolecular interactions.

Ndfip1 and Ndfip2. Studies during the past few years have shown that in $S$. cerevisiae, where there is a single Nedd4 family member Rsp5, a number of binding proteins regulate Rsp5p mediated ubiquitylation. One of these is Bsd2p, which acts as an adaptor for Rsp5p to control the trafficking of two vacuolar enzymes Cps1p and Phm5p ${ }^{61}$ and the metal-ion transporter Smf1p. ${ }^{62,63}$ Bsd2p homologues in mammals, Ndfip1 (N4WBP5, Nedd4 WW domain binding protein 5), and Ndfip2 (N4WBP5A) also act as adaptors for a number of the 
Nedd4 family members, to control ubiquitylation of specific targets. ${ }^{13}$ Ndfip1 was initially discovered as a Nedd4 WW domain-interacting protein (N4WBP5) in a far-Western screen. ${ }^{64}$ Ndfip2 was later identified as a closely related protein in the database. ${ }^{65-67}$ Ndfip1 and Ndfip2, through their three transmembrane domains localize to the golgi, golgiderived transport vesicles, endosomes and MVBs (multivesicular bodies), the subcellular sites of biosynthetic, secretory, and endocytic trafficking. Through their PY motifs, both Ndfips can interact with the WW domains in a number of the Nedd4 family members, including Nedd4, Nedd4-2, WWP1, WWP2, and Itch.

The gene KO data with Ndfip1 support the prediction from in vitro studies that Ndfips are crucial adaptor proteins. The KO animals die because of inflammatory disease caused by aberrant T-cell activation. ${ }^{68}$ Further analysis of the $\mathrm{KO}$ phenotype indicated that the loss of Ndfip1 leads to JunB accumulation. As JunB is normally targeted for degradation by Itch, the studies show that in T cells Ndfip1 acts as an adaptor for Itch to facilitate its interaction with JunB. ${ }^{68}$ In addition to Itch, the in vitro and KO studies indicate that Ndfip1 (and perhaps Ndfip2) also serve as physiological adaptors for another Nedd4 family member WWP2 to regulate the mammalian divalent metal-ion transporter DMT1. ${ }^{69}$ In the context of this review article, Ndfips are also predicted to regulate ubiquitylation by Nedd4 and Nedd4-2 as both proteins interact with these ligases. Ndfip1 expression has been shown to be neuroprotective following traumatic brain injury, ${ }^{70}$ but it is not known which E3 and what substrates are involved. It is interesting to note that Ndfip1 was recently shown to be involved in exosomal secretion in neurons and overexpression of Ndfip1 results in the recruitment of Nedd4, Nedd4-2, and Itch proteins in the exosomes. ${ }^{71}$ Ndfip2 overexpression in Xenopus oocytes inhibits the Nedd4-2mediated regulation of $\mathrm{ENaC}$, presumably by sequestering Nedd4-2 away from ENaC. ${ }^{66}$

14-3-3. 14-3-3s are ubiquitously expressed eukaryotic proteins that bind a phosphoserine or phosphothreonine motif in a large number of proteins. ${ }^{72}$ These proteins regulate signaling by providing scaffolding, by causing conformation change or by preventing the interaction of the target protein with other proteins. ${ }^{72}$ A number of studies have shown that 14-3-3 bind at least one discrete phosphoserine motif in Nedd4-2. ${ }^{73,74}$ A number of Ser/Thr kinases, including Sgk1, Akt, and IKK $\beta$ regulate the activity of $\mathrm{ENaC}$, and several studies have shown that $\mathrm{ENaC}$ regulation by these kinases, at least to some extent, is mediated through Nedd4-2 and 14-3-3 proteins. ${ }^{74-81}$ Insulin and aldosterone, two hormones that upregulate $\mathrm{ENaC}$ activity, in part do so by inducing Akt and Sgk1 activation (Figure 3). These kinases then phosphorylate specific Ser residue of Nedd4-2 contained in a 14-3-3 binding motif located between the WW domains. This phosphorylation results in the recruitment of 14-3-3 to Nedd4-2. The binding of 14-3-3 and Nedd4-2 prevents Nedd4-2 binding to ENaC and thus, circumventing the negative regulation of $\mathrm{ENaC}$ and allowing the channel to stay on the membrane (Figure 3).

Grb10 and ISG15. Recent work shows that Nedd4 is negatively regulated by a ubiquitin-like protein, ISG15. ${ }^{82}$
ISG15 binds Nedd4 and interferes with Nedd4 interaction with E2, thereby affecting the catalytic activity of Nedd4. This leads to an inhibition of the ability of Nedd4 to ubiquitylate viral matrix proteins and the release of virus particles. ${ }^{82}$

As discussed above, Grb10 protein binds Nedd4 to regulate IGF-1 and insulin signaling. ${ }^{30}$ Grb10 also regulates Nedd4mediated degradation of VEGF-R2. ${ }^{28}$ In this case Grb10 interacts with Nedd4 to prevent Nedd4-dependent degradation of VEGF-R2. However, in this pathway Nedd4 does not appear to directly ubiquitylate VEGF-R2. ${ }^{28}$ Nevertheless, in both cases binding of Grb10 to Nedd4 regulates Nedd4 function in specific signaling pathways.

Intramolecular interactions and protein conformation. There is evidence to suggest that intramolecular interaction can inhibit autoubiquitylation of Nedd4-2. ${ }^{83}$ It was found that the WW domains of Nedd4-2 weakly bind a LPXY motif located within its HECT domain. This intramolecular interaction inhibits autoubiquitylation of Nedd4-2. The mutation of the LPXY motif decreases the stability of Nedd42 protein, without affecting its ability to ubiquitylate ENaC. Based on these observations the authors have proposed a model, where the intramolecular interaction between WW domains and HECT stabilizes Nedd4-2 by preventing autoubiquitylation, whereas substrate binding disrupts this interaction, leading to Nedd4-2 downregulation. ${ }^{83}$

Sgk1 and Akt. As stated above Sgk1, which is an aldosterone- and insulin-dependent, positive regulator of $\mathrm{ENaC}$ density at the plasma membrane, has been shown to act through the phosphorylation of Nedd4-2 on one or more Ser/Thr consensus sites. ${ }^{75,76}$ Akt/ PKB (protein kinase B) can also phosphorylate the same Ser residue in Nedd4-2 as Sgk1, and indeed has a similar effect on ENaC. ${ }^{84}$ Phosphorylated Nedd4-2, with the phosphorylation sites within the WW domains, could interfere with the interaction with ENaC through its PY motif. ${ }^{75,76}$ Both ENaC and Sgk1 contain PY motifs that can be used for binding with Nedd4-2 through its WW domains, and it has been shown that the WW3 and WW4 domains of Nedd4-2 are responsible for binding to both Sgk1 and $\mathrm{ENaC}^{85}$.

Both Nedd4 and Nedd4-2 also undergo phosphorylation at multiple sites during mitosis. ${ }^{86}$ However, the function consequences of this phosphorylation and the kinases responsible have not been identified.

\section{Future Directions}

From the apparent non-overlapping phenotypes of the Nedd4 and Nedd4-2 gene KO mice it is clear that the main substrates of these E3s are distinct, despite the very close similarity between these two ubiquitin ligases. Although Nedd4 and Nedd4-2 show very similar binding affinities for the same substrates in vitro (e.g., both bind all three $\mathrm{ENaC}$ subunits in vitro with high affinity), mouse data suggest that in vivo their substrate binding may be more restricted than envisaged. Many of the channels, transporters, and other potential targets of Nedd4 and Nedd4-2 (Table 1) would need further validation, perhaps by the use of cells and tissues derived from the KO mice. Given the perinatal lethality of Nedd4 KO 
animals, it may be necessary to generate conditional $\mathrm{KO}$ mice to enable the study of physiological targets of Nedd4. It is possible that in some cases the functions of Nedd4 and Nedd4-2 are redundant. Thus, it may be informative to generate double $\mathrm{KO}$ mice.

It has been shown that accessory and adaptor proteins contribute to the specificity, diversity, and overall function of both Nedd4 and Nedd4-2. ${ }^{13}$ Identification and biochemical characterization of the interactomes for both Nedd4 and Nedd4-2 would facilite our understanding of these E3s and their substrates. To that end, systemic approaches using the current proteomic and bioinformatic techniques will be needed to generate the much desired information. The challenges for these approaches will include the low abundance of endogenous Nedd4 or Nedd4-2 and the potential false interactions sometimes associated with overexpression systems. It may be advantageous to tag the endogenous Nedd4 or Nedd4-2 using techniques, such as the TAP (tamdem affinity purification) tag. ${ }^{87}$

Nedd4 protein is known to be cleaved by caspases during apoptosis. ${ }^{88}$ The cleavage of Nedd4 removes the $\mathrm{N}$-terminal C2 domain from the rest of the protein without disrupting the WW domains and the HECT. The removal of the N-terminal region of Nedd 4 was reported to make the protein unstable, leading to the degradation of the WW-HECT cleavage product. ${ }^{88}$ As the functional significance of Nedd4 cleavage and degradation during apoptosis remains unknown, it may be interesting to study the apoptotic response of Nedd4-deficient cells from the $\mathrm{KO}$ animal.

Despite some recent advances, the regulation of Nedd4 and Nedd4-2 is still not fully understood. For example, many kinase seem to phosphorylate Nedd4 and Nedd4-2, but in most cases physiological relevance and link to cellular signaling seem unclear. Several proteins, such as Ndfip1 and Ndfip2, can bind both Nedd4 and Nedd4-2. However, it is not known whether the binding occurs in vivo and whether the adaptors are used by Nedd4 and/or Nedd4-2 to facilitate substrate recruitment and protein trafficking. In yeast $S$. cerevisiae Rsp5, the only Nedd4-like protein, uses many adaptor proteins, in addition to the Ndfip-like protein, Bsd2. ${ }^{13,89}$ One recently identified group of proteins, arrestinrelated proteins (ARTS), facilitates Rsp5 recruitment to plasma membrane proteins. ${ }^{90,91}$ Rsp5 then ubiquitylates specific targets at the membrane leading to their endocytosis. Further cellular and biochemical studies will be necessary to establish whether Nedd4 and Nedd4-2 also use ARTS in mammalian cells to recognize and bind their targets at the plasma membrane.

Acknowledgements. The work in the Yang laboratory is supported by the $\mathrm{NIH}$ (DK52617, AR052647, and DE16215 to BY), and in the Kumar Laboratory by the National Health and Medical Research Council (508086), and the Australian Research Council (DP0880571). We thank the members of our respective laboratories and Dr. Paula Oliver (Children's Hospital of Philadelphia) for helpful comments.

1. Ciechanover A. Proteolysis: From the lysosome to ubiquitin and the proteasome. Nat Rev $\mathrm{Mol}$ Cell Biol 2005; 6: 79-87.

2. Hershko A, Ciechanover A. The ubiquitin system. Annu Rev Biochem 1998; 67: 425-479.
3. Xu P, Duong DM, Seyfried NT, Cheng D, Xie Y, Robert J et al. Quantitative proteomics reveals the function of unconventional ubiquitin chains in proteasomal degradation. Cell 2009; 137: 133-145.

4. Rotin D, Kumar S. Physiological functions of the HECT family of ubiquitin ligases. Nat Rev Mol Cell Biol 2009; 10: 398-409.

5. Huibregtse JM, Scheffner M, Beaudenon S, Howley PM. A family of proteins structurally and functionally related to the E6-AP ubiquitin-protein ligase. Proc Natl Acad Sci USA 1995; 92: 2563-2567.

6. Kumar S, Tomooka Y, Noda M. Identification of a set of genes with developmentally down-regulated expression in the mouse brain. Biochem Biophys Res Commun 1992; 185: $1155-1161$.

7. Hein C, Springael JY, Volland C, Haguenauer-Tsapis R, Andre B. NPI1, an essential yeast gene involved in induced degradation of Gap1 and Fur4 permeases, encodes the Rsp5 ubiquitin-protein ligase. Mol Microbiol 1995; 18: 77-87.

8. Matentzoglu K, Scheffner M. Ubiquitin ligase E6-AP and its role in human disease. Biochem Soc Trans 2008; 36 (Pt 5): 797-801.

9. Scheffner M, Huibregtse JM, Vierstra RD, Howley PM. The HPV-16 E6 and E6-AP complex functions as a ubiquitin-protein ligase in the ubiquitination of p53. Cell 1993; 75 : 495-505.

10. Huang L, Kinnucan E, Wang G, Beaudenon S, Howley PM, Huibregtse JM et al. Structure of an E6AP-UbcH7 complex: Insights into ubiquitination by the E2-E3 enzyme cascade. Science 1999; 286: 1321-1326.

11. Harvey KF, Kumar S. Nedd4-like proteins: An emerging family of ubiquitin-protein ligases implicated in diverse cellular functions. Trends Cell Biol 1999; 9: 166-169.

12. Ingham RJ, Gish G, Pawson T. The Nedd4 family of E3 ubiquitin ligases: Functional diversity within a common modular architecture. Oncogene 2004; 23: 1972-1984.

13. Shearwin-Whyatt L, Dalton HE, Foot N, Kumar S. Regulation of functional diversity within the Nedd4 family by accessory and adaptor proteins. Bioessays 2006; 28: $617-628$.

14. Fotia AB, Cook DI, Kumar S. The ubiquitin-protein ligases Nedd4 and Nedd4-2 show similar ubiquitin-conjugating enzyme specificities. Int J Biochem Cell Biol 2006; 38: 472-479.

15. Kumar S, Harvey KF, Kinoshita M, Copeland NG, Noda M, Jenkins NA. CDNA cloning, expression analysis, and mapping of the mouse Nedd4 gene. Genomics 1997; 40: 435-443.

16. Harvey KF, Dinudom A, Komwatana P, Jolliffe CN, Day ML, Parasivam G et al. All three WW domains of murine Nedd4 are involved in the regulation of epithelial sodium channels by intracellular Na+. J Biol Chem 1999; 274: 12525-12530.

17. Plant PJ, Lafont F, Lecat S, Verkade P, Simons K, Rotin D. Apical membrane targeting of Nedd4 is mediated by an association of its C2 domain with annexin XIIlb. J Cell Biol 2000; 149: $1473-1484$.

18. Fotia AB, Dinudom A, Shearwin KE, Koch JP, Korbmacher C, Cook DI et al. The role of individual Nedd4-2 (KIAA0439) WW domains in binding and regulating epithelial sodium channels. FASEB J 2003; 17: 70-72.

19. Kanelis V, Bruce MC, Skrynnikov NR, Rotin D, Forman-Kay JD. Structural determinants for high-affinity binding in a Nedd4 WW $3^{*}$ domain-Comm PY motif complex. Structure 2006; 14: 543-553.

20. Itani OA, Campbell JR, Herrero J, Snyder PM, Thomas CP. Alternate promoters and variable splicing lead to $\mathrm{hNedd} 4-2$ isoforms with a $\mathrm{C} 2$ domain and varying number of WW domains. Am J Physiol Renal Physiol 2003; 285: F916-F929.

21. Itani $\mathrm{OA}$, Stokes JB, Thomas CP. Nedd4-2 isoforms differentially associate with $\mathrm{ENaC}$ and regulate its activity. Am J Physiol Renal Physiol 2005; 289: F334-F346.

22. Staub O, Dho S, Henry P, Correa J, Ishikawa T, McGlade J et al. WW domains of Nedd4 bind to the proline-rich PY motifs in the epithelial $\mathrm{Na}+$ channel deleted in Liddle's syndrome. EMBO J 1996; 15: 2371-2380.

23. Harvey KF, Dinudom A, Cook DI, Kumar S. The Nedd4-like protein KIAA0439 is a potential regulator of the epithelial sodium channel. J Biol Chem 2001; 276: 8597-8601.

24. Kamynina $E$, Debonneville $C$, Bens $M$, Vandewalle A, Staub O. A novel mouse Nedd4 protein suppresses the activity of the epithelial Na+ channel. FASEB J 2001; 15 : 204-214.

25. Snyder PM, Steines JC, Olson DR. Relative contribution of Nedd4 and Nedd4-2 to ENaC regulation in epithelia determined by RNA interference. J Biol Chem 2004; 279 : 5042-5046.

26. Morrione A, Plant $\mathrm{P}$, Valentinis $\mathrm{B}$, Staub $\mathrm{O}$, Kumar $\mathrm{S}$, Rotin D et al. mGrb10 Interacts with Nedd4. J Biol Chem 1999; 274: 24094-24099.

27. Katz M, Shtiegman K, Tal-Or P, Yakir L, Mosesson Y, Harari D et al. Ligand-independent degradation of epidermal growth factor receptor involves receptor ubiquitylation and $\mathrm{Hgs}$, an adaptor whose ubiquitin-interacting motif targets ubiquitylation by Nedd4. Traffic 2002; 3: $740-751$.

28. Murdaca J, Treins C, Monthouel-Kartmann MN, Pontier-Bres R, Kumar S, Van Obberghen E et al. Grb10 prevents Nedd4-mediated vascular endothelial growth factor receptor-2 degradation. J Biol Chem 2004; 279: 26754-26761.

29. Peruzzi F, Prisco M, Morrione A, Valentinis B, Baserga R. Anti-apoptotic signaling of the insulin-like growth factor-I receptor through mitochondrial translocation of c-Raf and Nedd4. J Biol Chem 2001; 276: 25990-25996.

30. Cao XR, Lill NL, Boase N, Shi PP, Croucher DR, Shan $\mathrm{H}$ et al. Nedd4 controls animal growth by regulating IGF-1 signaling. Sci Signal 2008; 1: ra5. 
31. Fouladkou F, Landry $\mathrm{T}$, Kawabe $\mathrm{H}, \mathrm{Neeb} \mathrm{A}$, Lu C, Brose $\mathrm{N}$ et al. The ubiquitin ligase Nedd4-1 is dispensable for the regulation of PTEN stability and localization. Proc Nat/ Acad Sci USA 2008; 105: 8585-8590.

32. Vecchione A, Marchese A, Henry P, Rotin D, Morrione A. The Grb10/Nedd4 complex regulates ligand-induced ubiquitination and stability of the insulin-like growth factor I receptor. Mol Cell Biol 2003; 23: 3363-3372.

33. Girnita L, Girnita A, Larsson O. Mdm2-dependent ubiquitination and degradation of the insulin-like growth factor 1 receptor. Proc Natl Acad Sci USA 2003; 100: 8247-8252.

34. Sehat B, Andersson S, Girnita L, Larsson O. Identification of c-Cbl as a new ligase for insulin-like growth factor-I receptor with distinct roles from Mdm2 in receptor ubiquitination and endocytosis. Cancer Res 2008; 68: 5669-5677.

35. Heissmeyer V, Macian F, Im SH, Varma R, Feske S, Venuprasad K et al. Calcineurin imposes T cell unresponsiveness through targeted proteolysis of signaling proteins. Nat Immunol 2004; 5: 255-265.

36. Mueller DL. E3 ubiquitin ligases as T cell anergy factors. Nat Immunol 2004; 5: 883-890.

37. Fang D, Elly C, Gao B, Fang N, Altman Y, Joazeiro C et al. Dysregulation of T lymphocyte function in itchy mice: A role for Itch in TH2 differentiation. Nat Immunol 2002; 3: 281-287.

38. Yang B, Gay DL, MacLeod MKL, Cao X, Sweezer EM, Kappler J et al. Nedd4 augments the adaptive immune response by promoting ubiquitin mediated degradation of $\mathrm{Cbl}-\mathrm{b}$ in activated T cells. Nat Immunol 2008; 9: 1356-1363.

39. Perry WL, Hustad CM, Swing DA, O'Sullivan TN, Jenkins NA, Copeland NG. The itchy locus encodes a novel ubiquitin protein ligase that is disrupted in $18 \mathrm{H}$ mice. Nat Genet 1998; 18: 143-146.

40. Magnifico A, Ettenberg S, Yang C, Mariano J, Tiwari S, Fang S et al. WW domain HECT E3s target Cbl RING finger E3s for proteasomal degradation. J Biol Chem 2003; 278: 43169-43177.

41. Liu Y, Oppenheim RW, Sugiura Y, Lin W. Abnormal development of the neuromuscular junction in Nedd4-deficient mice. Dev Biol 2009; 330: 153-166.

42. Giorgetti-Peraldi S, Murdaca J, Mas JC, Van Obberghen E. The adapter protein, Grb10, is a positive regulator of vascular endothelial growth factor signaling. Oncogene 2001; 20: 3959-3968.

43. Wang X, Trotman LC, Koppie T, Alimonti A, Chen Z, Gao Z et al. NEDD4-1 is a protooncogenic ubiquitin ligase for PTEN. Cell 2007; 128: 129-139.

44. Trotman LC, Wang X, Alimonti A, Chen Z, Teruya-Feldstein J, Yang H et al. Ubiquitination regulates PTEN nuclear import and tumor suppression. Cell 2007; 128: 141-156.

45. Dimmock NJ. Introduction to Modern Virology. 6th edn. Blackwell Science: Oxford, Cambridge, MA, USA, 2007.

46. Ikeda M, Ikeda A, Longan LC, Longnecker R. The Epstein-Barr virus latent membrane protein 2A PY motif recruits WW domain-containing ubiquitin-protein ligases. Virology 2000; 268: 178-191.

47. Strack B, Calistri A, Accola MA, Palu G, Gottlinger HG. A role for ubiquitin ligase recruitment in retrovirus release. Proc Natl Acad Sci USA 2000; 97: 13063-13068.

48. Harty RN, Brown ME, Wang G, Huibregtse J, Hayes FP. A PPxY motif within the VP40 protein of Ebola virus interacts physically and functionally with a ubiquitin ligase: Implications for filovirus budding. Proc Natl Acad Sci USA 2000; 97: 13871-13876.

49. Pradervand S, Vandewalle A, Bens M, Gautschi I, Loffing J, Hummler E et al. Dysfunction of the epithelial sodium channel expressed in the kidney of a mouse model for Liddle syndrome. J Am Soc Nephrol 2003; 14: 2219-2228.

50. Shi PP, Cao XR, Sweezer EM, Kinney TS, Williams NR, Husted RF et al. Salt-sensitive hypertension and cardiac hypertrophy in mice deficient in the ubiquitin ligase Nedd4-2. Am J Physiol Renal Physiol 2008; 295: F462-F470.

51. Pradervand S, Wang Q, Burnier M, Beermann F, Horisberger JD, Hummler E et al. A mouse model for Liddle's syndrome. J Am Soc Nephrol 1999; 10: 2527-2533.

52. Fotia AB, Ekberg J, Adams DJ, Cook DI, Poronnik P, Kumar S. Regulation of neuronal voltage-gated sodium channels by the ubiquitin-protein ligases Nedd4 and Nedd4-2. J Biol Chem 2004; 279: 28930-28935.

53. Rougier JS, van Bemmelen MX, Bruce MC, Jespersen T, Gavillet B, Apotheloz F et al. Molecular determinants of voltage-gated sodium channel regulation by the Nedd4/Nedd4like proteins. Am J Physiol Cell Physiol 2005; 288: C692-C701.

54. van Bemmelen MX, Rougier JS, Gavillet B, Apotheloz F, Daidie D, Tateyama M et al. Cardiac voltage-gated sodium channel Nav1.5 is regulated by Nedd4-2 mediated ubiquitination. Circ Res 2004; 95: 284-291.

55. Brickley DR, Mikosz CA, Hagan CR, Conzen SD. Ubiquitin modification of serum and glucocorticoid-induced protein kinase-1 (SGK-1). J Biol Chem 2002; 277: 43064-43070.

56. Zhou R, Snyder PM. Nedd4-2 phosphorylation induces serum and glucocorticoidregulated kinase (SGK) ubiquitination and degradation. $J$ Biol Chem 2005; 280: 4518-4523.

57. Kotorashvili A, Russo SJ, Mulugeta S, Guttentag SH, Beers MF. Anterograde transport of surfactant protein $\mathrm{C}$ proprotein to distal processing compartments requires PPDY mediated association with NEDD4 ubiquitin ligases. J Biol Chem 2009; 284: 16667-16678.

58. Conkright J, Apsley KS, Martin E, Ridsdale R, Rice WR, Cheng-Lun Na C-L et al. Nedd4-2 mediated ubiquitination facilitates processing of surfactant protein C. Am J Resp Cell Mol 2009. in press.

59. Farrell PM, Avery ME. Hyaline membrane disease. Am Rev Respir Dis 1975; 111: 657-688.
60. Nogee LM, Dunbar 3rd AE, Wert SE, Askin F, Hamvas A, Whitsett JA. A mutation in the surfactant protein $\mathrm{C}$ gene associated with familial interstitial lung disease. $N$ Engl $J$ Med 2001; 344: 573-579.

61. Hettema EH, Valdez-Taubas J, Pelham HR. Bsd2 binds the ubiquitin ligase Rsp5 and mediates the ubiquitination of transmembrane proteins. EMBO J 2004; 23: 1279-1288.

62. Liu XF, Supek F, Nelson N, Culotta VC. Negative control of heavy metal uptake by the Saccharomyces cerevisiae BSD2 gene. J Biol Chem 1997; 272: 11763-11769.

63. Stimpson HE, Lewis MJ, Pelham HR. Transferrin receptor-like proteins control the degradation of a yeast metal transporter. EMBO J 2006; 25: 662-672.

64. Jolliffe CN, Harvey KF, Haines BP, Parasivam G, Kumar S. Identification of multiple proteins expressed in murine embryos as binding partners for the WW domains of the ubiquitin-protein ligase nedd4. Biochem J 2000; 351 (Pt 3): 557-565.

65. Harvey KF, Shearwin-Whyatt LM, Fotia A, Parton RG, Kumar S. N4WBP5, a potential target for ubiquitination by the Nedd4 family of proteins, is a novel Golgi-associated protein. J Biol Chem 2002; 277: 9307-9317.

66. Konstas AA, Shearwin-Whyatt LM, Fotia AB, Degger B, Riccardi D, Cook DI et al. Regulation of the epithelial sodium channel by N4WBP5A, a novel Nedd4/Nedd4-2interacting protein. J Biol Chem 2002; 277: 29406-29416.

67. Shearwin-Whyatt LM, Brown DL, Wylie FG, Stow JL, Kumar S. N4WBP5A (Ndfip2), a Nedd4-interacting protein, localizes to multivesicular bodies and the golgi, and has a potential role in protein trafficking. J Cell Sci 2004; 117 (Pt 16): 3679-3689.

68. Oliver PM, Cao X, Worthen GS, Shi P, Briones N, MacLeod M et al. Ndfip1 protein promotes the function of itch ubiquitin ligase to prevent $\mathrm{T}$ cell activation and Thelper 2 cell-mediated inflammation. Immunity 2006; 25: 929-940.

69. Foot NJ, Dalton HE, Shearwin-Whyatt LM, Dorstyn L, Tan SS, Yang B et al. Regulation of the divalent metal ion transporter DMT1 and iron homeostasis by a ubiquitin-dependent mechanism involving Ndfips and WWP2. Blood 2008; 112: 4268-4275.

70. Sang Q, Kim MH, Kumar S, Bye N, Morganti-Kossman MC, Gunnersen J et al. Nedd4WW domain-binding protein 5 (Ndfip1) is associated with neuronal survival after acute cortical brain injury. J Neurosci 2006; 26: 7234-7244.

71. Putz U, Howitt J, Lackovic J, Foot N, Kumar S, Silke J et al. Nedd4 family-interacting protein 1 (Ndfip1) is required for the exosomal secretion of Nedd4 family proteins. $J$ Biol Chem 2008; 283: 32621-32627.

72. Bridges D, Moorhead GB. 14-3-3 proteins: A number of functions for a numbered protein. Sci STKE 2005; 2005: re10.

73. Bhalla V, Daidie D, Li H, Pao AC, LaGrange LP, Wang J et al. Serum- and glucocorticoidregulated kinase 1 regulates ubiquitin ligase neural precursor cell-expressed, developmentally down-regulated protein 4-2 by inducing interaction with 14-3-3. Mol Endocrinol 2005; 19: 3073-3084.

74. Ichimura T, Yamamura H, Sasamoto K, Tominaga Y, Taoka M, Kakiuchi K et al. 14-3-3 proteins modulate the expression of epithelial $\mathrm{Na}+$ channels by phosphorylation-dependent interaction with Nedd4-2 ubiquitin ligase. J Biol Chem 2005; 280: 13187-13194.

75. Debonneville C, Flores SY, Kamynina E, Plant PJ, Tauxe C, Thomas MA et al. Phosphorylation of Nedd4-2 by Sgk1 regulates epithelial $\mathrm{Na}(+)$ channel cell surface expression. EMBO J 2001; 20: 7052-7059.

76. Snyder PM, Olson DR, Thomas BC. Serum and glucocorticoid-regulated kinase modulates Nedd4-2-mediated inhibition of the epithelial Na+ channel. J Biol Chem 2002; 277: 5-8.

77. Liang X, Peters KW, Butterworth MB, Frizzell RA. 14-3-3 isoforms are induced by aldosterone and participate in its regulation of epithelial sodium channels. J Biol Chem 2006; 281: 16323-16332.

78. Nagaki K, Yamamura H, Shimada S, Saito T, Hisanaga SI, Taoka M et al. 14-3-3 mediates phosphorylation-dependent inhibition of the interaction between the ubiquitin E3 ligase Nedd4-2 and epithelial $\mathrm{Na}(+)$ channels. Biochemistry 2006; 45: 6733-6740.

79. Lee IH, Dinudom A, Sanchez-Perez A, Kumar S, Cook DI. Akt mediates the effect of insulin on epithelial sodium channels by inhibiting Nedd4-2. J Biol Chem 2007; 282: 29866-29873

80. Liang X, Butterworth MB, Peters KW, Walker WH, Frizzell RA. An obligatory heterodimer of 14-3-3beta and 14-3-3epsilon is required for aldosterone regulation of the epithelial sodium channel. J Biol Chem 2008; 283: 27418-27425.

81. Edinger RS, Lebowitz J, Li H, Alzamora R, Wang H, Johnson JP et al. Functional regulation of the epithelial $\mathrm{Na}+$ channel by I\{kappa\}B kinase-\{beta\} occurs via phosphorylation of the ubiquitin ligase Nedd4-2. J Biol Chem 2009; 284: 150-157.

82. Malakhova OA, Zhang DE. ISG15 inhibits Nedd4 ubiquitin E3 activity and enhances the innate antiviral response. J Biol Chem 2008; 283: 8783-8787.

83. Bruce C, Kanelis V, Fouladkou F, Debonneville A, Staub O, Rotin D. Regulation of Nedd4-2 self-ubiquitylation and stability by a PY motif located within its HECT-domain. Biochem J 2008; 415: 155-163.

84. Dieter M, Palmada M, Rajamanickam J, Aydin A, Busjahn A, Boehmer C et al. Regulation of glucose transporter SGLT1 by ubiquitin ligase Nedd4-2 and kinases SGK1, SGK3, and PKB. Obes Res 2004; 12: 862-870.

85. Asher C, Sinha I, Garty H. Characterization of the interactions between Nedd4-2, ENaC, and sgk-1 using surface plasmon resonance. Biochim Biophys Acta 2003; 1612: 59-64.

86. Dephoure N, Zhou C, Villen J, Beausoleil SA, Bakalarski CE, Elledge SJ et al. A quantitative atlas of mitotic phosphorylation. Proc Natl Acad Sci USA 2008; 105: 10762-10767.

87. Angrand PO, Segura I, Volkel P, Ghidelli S, Terry R, Brajenovic M et al. Transgenic mouse proteomics identifies new 14-3-3-associated proteins involved in cytoskeletal rearrangements and cell signaling. Mol Cell Proteomics 2006; 5: 2211-2227. 
88. Harvey KF, Harvey NL, Michael JM, Parasivam G, Waterhouse N, Alnemri ES et al. Caspase-mediated cleavage of the ubiquitin-protein ligase Nedd4 during apoptosis. J Biol Chem 1998; 273: 13524-13530.

89. Leon S, Erpapazoglou Z, Haguenauer-Tsapis R. Ear1p and Ssh4p are new adaptors of the ubiquitin ligase Rsp5p for cargo ubiquitylation and sorting at multivesicular bodies Mol Biol Cell 2008; 19: 2379-2388.

90. Lin CH, MacGurn JA, Chu T, Stefan CJ, Emr SD. Arrestin-related ubiquitin-ligase adaptors regulate endocytosis and protein turnover at the cell surface. Cell 2008; 135: 714-725.

91. Nikko E, Sullivan JA, Pelham HR. Arrestin-like proteins mediate ubiquitination and endocytosis of the yeast metal transporter Smf1. EMBO Rep 2008; 9: 1216-1221.

92. Shenoy SK, Xiao K, Venkataramanan V, Snyder PM, Freedman NJ, Weissman AM. Nedd4 mediates agonist-dependent ubiquitination, lysosomal targeting, and degradation of the beta2-adrenergic receptor. J Biol Chem 2008; 283: 22166-22176.

93. Lafont $\mathrm{F}$, Simons K. Raft-partitioning of the ubiquitin ligases $\mathrm{Cb}$ and Nedd4 upon lgEtriggered cell signaling. Proc Natl Acad Sci USA 2001; 98: 3180-3184.

94. Leykauf K, Salek M, Bomke J, Frech M, Lehmann WD, Durst M et al. Ubiquitin protein ligase Nedd4 binds to connexin43 by a phosphorylation-modulated process. J Cell Sci 2006; 119 (Pt 17): 3634-3642.

95. Aoh $\mathrm{QL}$, Castle AM, Hubbard $\mathrm{CH}$, Katsumata O, Castle JD. SCAMP3 negatively regulates EGFR degradation and promotes receptor recycling. Mol Biol Cell 2009; 20: 1816-1832.

96. Dinudom A, Harvey KF, Komwatana P, Young JA, Kumar S, Cook DI. Nedd4 mediates control of an epithelial $\mathrm{Na}+$ channel in salivary duct cells by cytosolic $\mathrm{Na}+$. Proc $\mathrm{Natl}$ Acad Sci USA 1998; 95: 7169-7173.

97. Rost M, Doring T, Prange R. Gamma 2-adaptin, a ubiquitin-interacting adaptor, is a substrate to coupled ubiquitination by the ubiquitin ligase Nedd4 and functions in the endosomal pathway. J Biol Chem 2008; 283: 32119-32130.

98. Plant PJ, Correa J, Goldenberg NM, Bain J, Batt JA. The inositol phosphatase MTMR4 is a novel target of the ubiquitin ligase Nedd4. Biochem J 2009; 419: 57-63.

99. Koncarevic A, Jackman RW, Kandarian SC. The ubiquitin-protein ligase Nedd4 targets Notch1 in skeletal muscle and distinguishes the subset of atrophies caused by reduced muscle tension. FASEB J 2007; 21: 427-437.

100. Fedoroff OY, Townson SA, Golovanov AP, Baron M, Avis JM. The structure and dynamics of tandem WW domains in a negative regulator of notch signaling, Suppressor of deltex. J Biol Chem 2004; 279: 34991-35000.

101. Anindya R, Aygun O, Svejstrup JQ. Damage-induced ubiquitylation of human RNA polymerase II by the ubiquitin ligase Nedd4, but not Cockayne syndrome proteins or BRCA1. Mol Cell 2007; 28: 386-397.

102. Moren A, Imamura T, Miyazono K, Heldin CH, Moustakas A. Degradation of the tumor suppressor Smad4 by WW and HECT-domain ubiquitin ligases. J Biol Chem 2005; 280 22115-22123.

103. Al Sorkhy M, Craig R, Market B, Ard R, Porter LA. The cyclin-dependent kinase activator, Spy $1 A$, is targeted for degradation by the ubiquitin ligase NEDD4. J Biol Chem 2009; 284 2617-2627.

104. Chan W, Tian R, Lee YF, Sit ST, Lim L, Manser E. Down-regulation of active ACK1 is mediated by association with the E3 ubiquitin ligase Nedd4-2. J Biol Chem 2009; 284 8185-8194.
105. Hatanaka T, Hatanaka $Y$, Setou M. Regulation of amino acid transporter ATA2 by ubiquitin ligase Nedd4-2. J Biol Chem 2006; 281: 35922-35930.

106. Hryciw DH, Ekberg J, Lee A, Lensink IL, Kumar S, Guggino WB et al. Nedd4-2 functionally interacts with $\mathrm{CIC}-5$ : Involvement in constitutive albumin endocytosis in proximal tubule cells. J Biol Chem 2004; 279: 54996-55007.

107. Embark HM, Bohmer C, Palmada M, Rajamanickam J, Wyatt AW, Wallisch S et al. Regulation of CLC-Ka/barttin by the ubiquitin ligase Nedd4-2 and the serum- and glucocorticoid-dependent kinases. Kidney Int 2004; 66: 1918-1925.

108. Sorkina T, Miranda M, Dionne KR, Hoover BR, Zahniser NR, Sorkin A. RNA interference screen reveals an essential role of Nedd4-2 in dopamine transporter ubiquitination and endocytosis. J Neurosci 2006; 26: 8195-8205.

109. Boehmer C, Palmada M, Rajamanickam J, Schniepp R, Amara S, Lang F. Posttranslational regulation of EAAT2 function by co-expressed ubiquitin ligase Nedd4-2 is impacted by SGK kinases. J Neurochem 2006; 97: 911-921.

110. Boehmer C, Henke G, Schniepp R, Palmada M, Rothstein JD, Broer S et al. Regulation of the glutamate transporter EAAT1 by the ubiquitin ligase Nedd4-2 and the serum and glucocorticoid-inducible kinase isoforms SGK1/3 and protein kinase B. J Neurochem 2003; 86: 1181-1188.

111. Ekberg J, Schuetz F, Boase NA, Conroy SJ, Manning J, Kumar S et al. Regulation of the voltage-gated $\mathrm{K}(+)$ channels $\mathrm{KCNQ} 2 / 3$ and $\mathrm{KCNQ} 3 / 5$ by ubiquitination. Novel role for Nedd4-2. J Biol Chem 2007; 282: 12135-12142.

112. Jespersen T, Membrez M, Nicolas CS, Pitard B, Staub O, Olesen SP et al. The KCNQ1 potassium channel is down-regulated by ubiquitylating enzymes of the Nedd4/Nedd4-like family. Cardiovasc Res 2007; 74: 64-74.

113. Henke G, Maier G, Wallisch S, Boehmer C, Lang F. Regulation of the voltage gated $\mathrm{K}+$ channel Kv1.3 by the ubiquitin ligase Nedd4-2 and the serum and glucocorticoid inducible kinase SGK1. J Cell Physiol 2004; 199: 194-199.

114. Baltaev R, Strutz-Seebohm N, Korniychuk G, Myssina S, Lang F, Seebohm G. Regulation of cardiac shal-related potassium channel $\mathrm{Kv} 4.3$ by serum- and glucocorticoid-inducible kinase isoforms in Xenopus oocytes. Pflugers Arch 2005; 450: 26-33.

115. Palmada M, Dieter M, Speil A, Bohmer C, Mack AF, Wagner HJ et al. Regulation of intestinal phosphate cotransporter NaPi llb by ubiquitin ligase Nedd4-2 and by serumand glucocorticoid-dependent kinase 1. Am J Physiol Gastrointest Liver Physiol 2004; 287: G143-G150

116. Kuratomi G, Komuro A, Goto K, Shinozaki M, Miyazawa K, Miyazono K et al. NEDD4-2 (neural precursor cell expressed, developmentally down-regulated 4-2) negatively regulates TGF-beta (transforming growth factor-beta) signalling by inducing ubiquitinmediated degradation of Smad2 and TGF-beta type I receptor. Biochem J 2005; 386 (Pt 3): 461-470.

117. Arevalo JC, Waite J, Rajagopal R, Beyna M, Chen ZY, Lee FS et al. Cell survival through Trk neurotrophin receptors is differentially regulated by ubiquitination. Neuron 2006; $\mathbf{5 0}$ : 549-559.

118. He Y, Hryciw DH, Carroll ML, Myers SA, Whitbread AK, Kumar S et al. The ubiquitinprotein ligase Nedd4-2 differentially interacts with and regulates members of the Tweety family of chloride ion channels. J Biol Chem 2008; 283: 24000-24010. 